\title{
COMUNICAÇÃO
}

\section{ACUTE CHAGAS' CARDIOPATHY IN A POLAR BEAR (URSUS MARITIMUS) IN GUADALAJARA, MEXICO}

\author{
J. Jaime-Andrade G., David Avila-Figueroa, Felipe J. Lozano-Kasten, \\ René J. Hernández-Gutiérrez, Ezequiel Magallón-Gastélum, Marina J. \\ Kasten-Monges and Edison Reis Lopes
}

\begin{abstract}
We report a 24 year old female polar bear (Ursus maritimus) who contracted Chagas' infection at the Guadalajara Zoo, in Jalisco, México, and died of acute Chagas' carditis 15 days later. The histopathological findings are described, as well as the presence of triatomines (Triatoma longipennis Usinger) infected with Trypanosoma cruzi collected within 5 meters from the place where the animal lived in the city of Guadalajara.

Key-words: Chagas' carditis. Ursus maritimus. American trypanosomiasis.
\end{abstract}

The evidence of natural infection by Trypanosoma cruzi in animals in which Chagas disease (ChD) had not been previously described can contribute to a better understanding of many aspects of American trypanosomiasis. On this basis, we report here a case of acute Chagas' heart disease in a polar bear (Ursus maritimus) which occurred at the Guadajalara zoo in the State of Jalisco, Mexico.

Case description. A 24 year old Ursus maritimus female entered the Guadalajara zoo on June 28th 1994. The animal had been brought from the United States where she lived in a zoo in the Great Lakes area. During 10 months of captivity in the Guadalajara zoo, the bear presented five episodes of ascaridiasis and was treated with mebendazole. On March 12th 1995 she had no appetite, did not move and was somnolent. A few days later, she had a high temperature and developed tachycardia. Fifteen days after the beginning of these symptoms she was found dead in her artificial habitat.

After death, a $1.5 \times 1.0 \mathrm{~cm}$ heart fragment was taken from the left ventricle, fixed in $10 \%$ formalin, and routinely processed for histology by paraffin embedding 12 . The sections were

\footnotetext{
* Zoológico Guadalajara, Departamento de Patologia Animal del CUBA y Centro de Investigación en Enfermedades Tropicales del Departamento de Salúd Pública del CUCS de la Universidad de Guadalajara, Jalisco, México y Curso de Pós-graduação en Patologia Humana da Faculdade de Medicina do Triângulo Mineiro, Uberaba, MG, Brasil.

Address to: Prof. Edison Reis Lopes,Av. Getúlio Guaritá, 130, 38025-440, Uberaba, MG, Brazil. Phone: 55 (021) 318-5154. Recebido para publicação em 10/01/97.
}

mounted on histopathologic slides and stained with hematoxylin-eosin, Masson's trichrome and Giemsa. The peroxidase-antiperoxidase (PAP) immunocytochemical method was applied as described by Barbosa1 with the use of anti-T. cruzi antibodies. The material was then submitted to amplification by the polymerase chain reaction (PCR) by the method of Sturm et al.13.

Histopathologic examination (Figures 1, 3 and 4) showed myocarditis which was diffuse in most fields due to the confluence of multiple focal points of inflammation. In addition to congestion and edema there was an intensive infiltrate of macrophages, lymphocytes and their derivatives (blast cells and plasmocytes), and variable amount of granulocytes, neutrophils and eosinophils. These elements of exudation were localized in the endomysium, dissociating and separating the fiber cells from the capillaries, at time extending to the epicardium, and from it to the vascular adventitia. Extensive necrotic-degenerative damage to myocells was associated with the exudate phenomenon. There was an intensive focal and diffuse acute epicarditis with marked parasitism. A mild focal acute parietal endocarditis was also detected. Parasitism was intensive with the presence of many forms of T. cruzi amastigote nests (Figure 2) inside the myocells and macrophages or free in the interstitium. PCR amplification was positive to T. cruzi. The DNA extracted from the histopathologic slides was amplified using primers homologous to the variable region of T. cruzi R DNA. 
Comunicação. Jaime-Andrade G J, Avila-Figueroa D, Lozano-Kasten FJ, Hernández-Guitiérrez RJ, MagallónGastélum E, Kasten-Monges JK, Lopes ER. Acute Chagas' cardiopathy in polar bear (Ursus maritimus) in Guadalajara, Mexico. Revista da Sociedade Brasileira de Medicina Tropical 30:337-340, jul-ago, 1997.

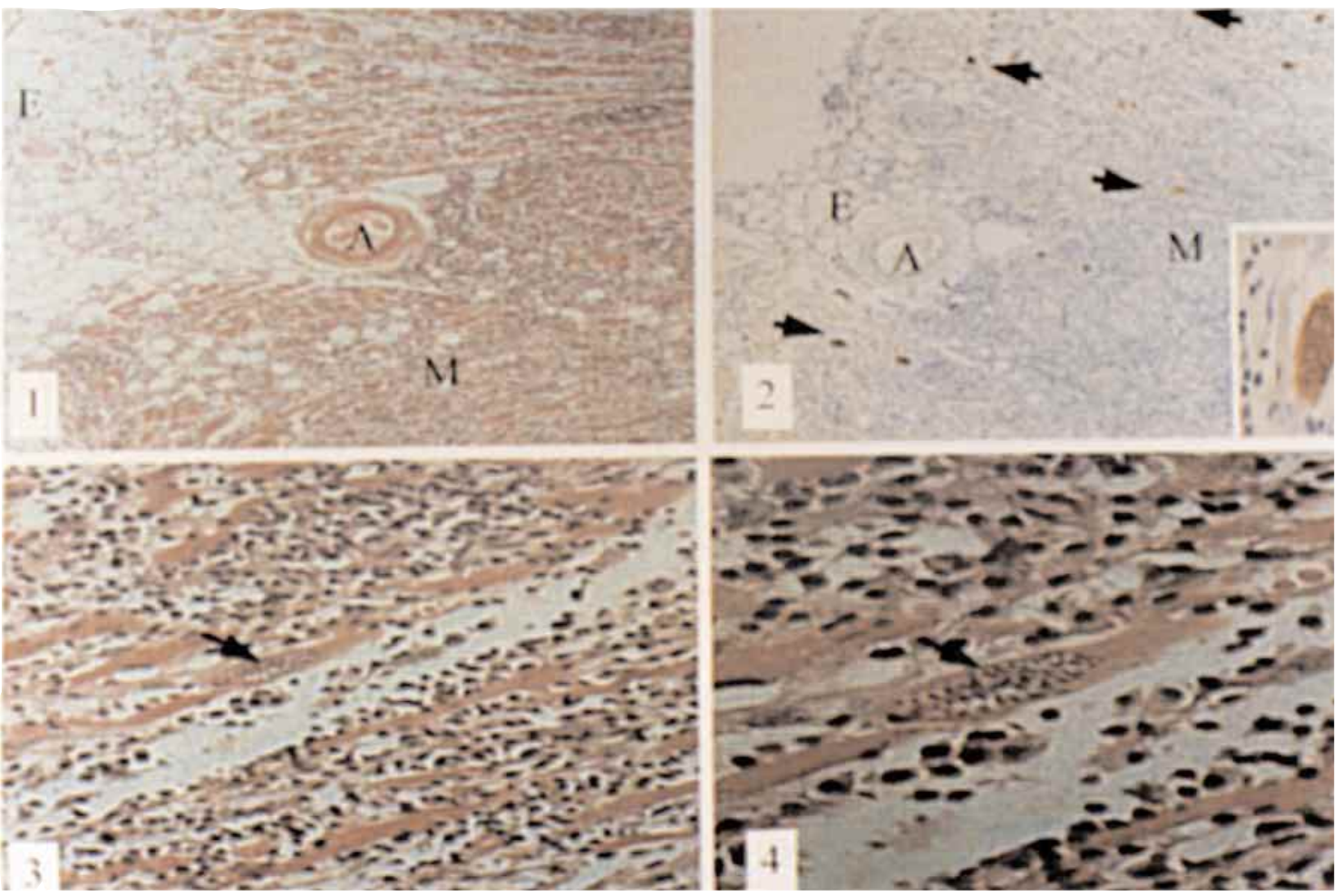

Figure 1 - Hematoxilin and eosin stained section of the left ventricular wall showing acute diffuse myocarditis (M) and epicarditis (E). A indicates cross section of an epicardial coronary artery (original magnification x 40).

Figure 2 - Left ventricular wall stained with peroxidase-antiperoxidase immunocytochemical method. Note the presence of numerous T. cruzi amastigotes (arrows; original magnification $\mathrm{x} 40$ ). Inset is a higher magnification view of $\mathrm{T}$. cruzi amastigote nest

Figure 3 - Chagasic acute diffuse myocarditis with T. cruzi amastigotes (arrow) filling up myocell (original magnification $\mathrm{x}$ 100). Hematoxylin and eosin stain.

Figure 4 - Higher magnification view of Figure 3 (original magnification x 200). Hematoxilin and eosin stain.

After establishing a diagnosis of $\mathrm{ChD}$, the presence of T. cruzi-infected triatomines identified as Triatoma longipennis Usinger ${ }^{9}$ was detected 5 meters from the place where the bear lived in the Guadalajara zoo (Figure 5). This species is the most widely distributed in the state of Jalisco and is also the species most frequently parasitized by $\mathrm{T}$. cruzi 10 .

Comments. The histophatologic study of the heart was conclusive for the diagnosis of $\mathrm{ChD}$ which, to our knowledge, is reported in a polar bear for the first time. Our findings not only confirm the fact that the etiologic agent of American Trypanosomiasis is extremely eclectic in terms of vertebrate hosts but add to the number of mammals in which the infection has been proved11.
The present results lead us to conclude that the bear acquired the infection from infected triatomines which were collected near its habitat. The fact that bears are covered with a dense and thick coat makes it difficult to believe that T. cruzi transmission was caused by the feces of infected triatomines through the skin or mucous of the animal. It seems more likely that transmission occurred in the digestive tract through the ingestion of infected triatomines. This mechanism has been confirmed experimentally, in other animals 4 . The ingestion of triatomines seems to be common among animals4, and bears, although classified as carnivorous, are omnivorous.

An important fact in the present study was the possibility of clarifying some of the 
Comunicação. Jaime-Andrade G J, Avila-Figueroa D, Lozano-Kasten FJ, Hernández-Guitiérrez RJ, MagallónGastélum E, Kasten-Monges JK, Lopes ER. Acute Chagas' cardiopathy in polar bear (Ursus maritimus) in Guadalajara, Mexico. Revista da Sociedade Brasileira de Medicina Tropical 30:337-340, jul-ago, 1997.

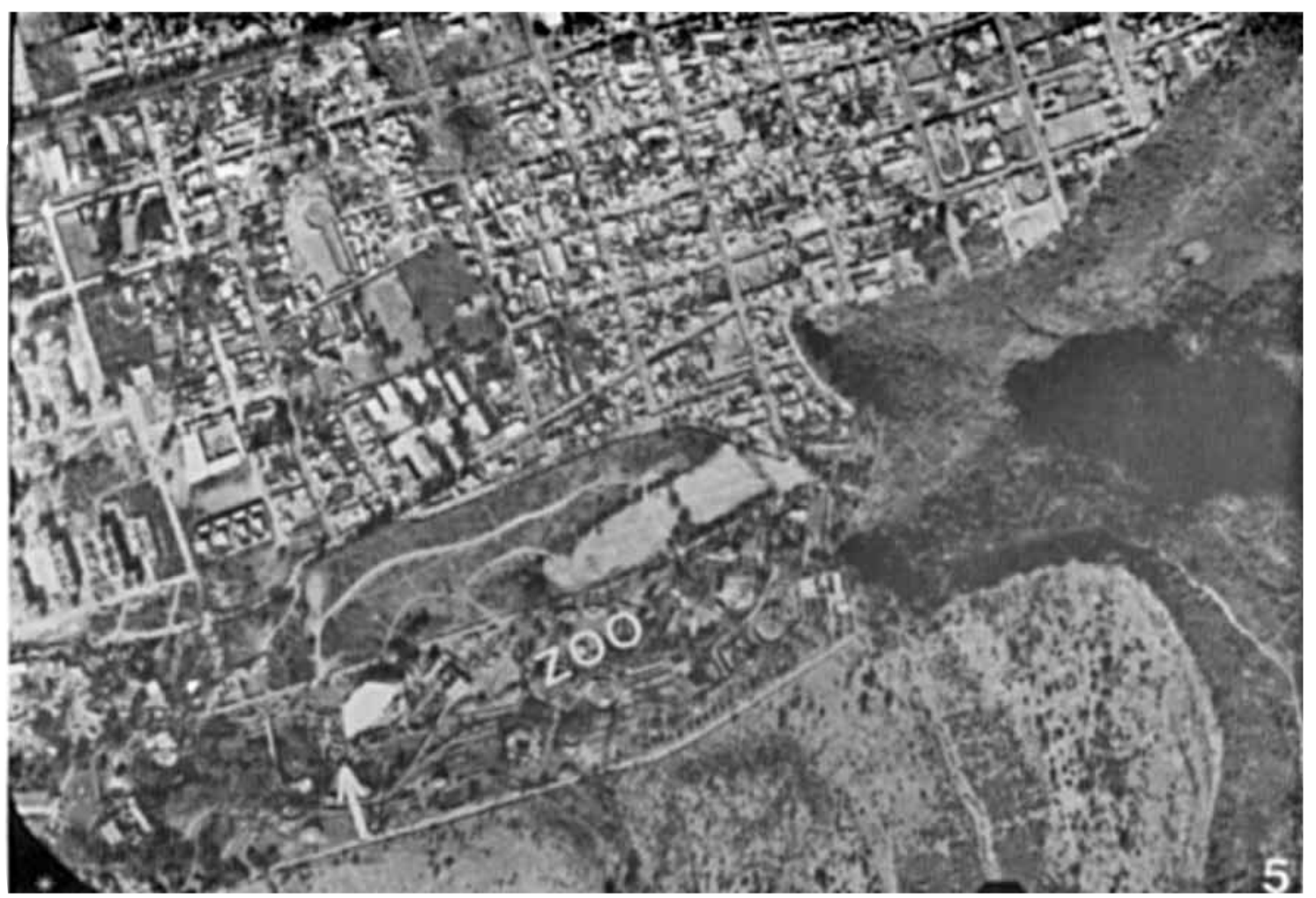

Figure 5 - Air view of the Guadalajara zoologic (zoo). Note the place where the bear lived (arrow). Five meters from this place was detected T. cruzi infected triatomines (Triatoma longipennis Usinger).

characteristics of the infection, which permit us to speculate about cases such as that reported by Malamos in Hamburg in 19533. On that occasion trypanosomes morphologically identical to T. cruzi were detected in the blood of four monkeys from the island of Java. With the feces of triatomines infected from these monkeys it was possible to reproduce the infection in rats, wich resulted in the finding of T. cruzi in the heart and muscles. Based on these findings, the hypothesis was raised that Chagas' infection may occur in Indonesia, although this fact has not yet been confirmed. The present data and the fact that infected triatomines are occasionally found in houses, closets, suitcases, etc. led us to suspect, as Hoare in 19637, that in cases like those reported by Malamos the infection may have ocurred in areas other than the site of origin of the monkeys.

The acute Chagas' carditis reported here presented histophatologic characteristics quite similar to those described in man and other animals 2 . Particularly striking were the intensive exsudative and necrotic degenerative phenomena in the myocardium as well as the massive parasitism observed.

The T. cruzi-infected triatomines found in a zoo located in the metropolitan north zone of Guadalajara, Jalisco, where human ChD was notified for the first time in 19675, and where high rates of T. cruzi infection $(82.3 \%)$ where found in some municipalities in a state sample of about 13,274 individuals with a general index of $17.7 \%$ in Jalisco state6, and where other human cases had been described8, should have alerted the authorities. The Guadalajara zoo is surrounded to the north by a wild ecotope known as "La Barranca de Huentitán" and by residential projects to the west and south (Figure 5). The zoo keeps its vegetation and conditions practically natural. 
Comunicação. Jaime-Andrade G J, Avila-Figueroa D, Lozano-Kasten FJ, Hernández-Guitiérrez RJ, MagallónGastélum E, Kasten-Monges JK, Lopes ER. Acute Chagas' cardiopathy in polar bear (Ursus maritimus) in Guadalajara, Mexico. Revista da Sociedade Brasileira de Medicina Tropical 30:337-340, jul-ago, 1997.

Finally it is important to emphasize that an animal who can live as long as 30 years was infected at 24 years of age. In 1993 LozanoKasten et al8 described an acute ChD case involving an 80-year-old Guadalajara woman, an age at which an initial infection by T. cruzi is not frequent.

\section{RESUMO}

Relatamos o caso de uma ursa polar (Ursus maritimus) de 24 anos de idade, que contraiu a infecção chagásica no Zoológico de Guadalajara, em Jalisco, no México, e morreu de cardite chagásica aguda 15 dias após o início da sintomatologia. Os achados histopatológicos são descritos, bem como a presença de triatomíneos (Triatoma longipennis Usinger) infectados por Trypanosoma cruzi coletados a 5 metros do local onde o animal vivia, na cidade de Guadalajara.

Palavras-chaves: Cardite chagásica. Ursus maritimus. American trypanosomiasis.

\section{ACKNOWLEDGEMENTS}

We are grateful to Professors Geraldo Brasileiro Filho and Sérgio Pena for their help in the PCR amplification study and to Professor Aluizio Prata for valuable suggestions.

\section{REFERENCES}

1. Barbosa AJA. Método imunocitoquímico para a identificação do Trypanosoma cruzi em cortes histológicos de rotina. Revista do Instituto de MedicinaTropical de São Paulo 27:293-297, 1985.

2. Chapadeiro E, Tafuri W, Lopes ER. Anatomia patológica da cardiopatia aguda. In: Cançado JR, Chuster M (eds). Cardiopatia chagásica. Fundação Carlos Chagas, Belo Horizonte, p.29-32, 1985.

3. Coutinho E. Trypanosomiase americana. In: Coutinho E (ed). Tratado de clínica das doenças infecctuosas e parasitárias. Guanabara Koogan, Rio de Janeiro, p.372-389, 1951.

4. Dias JCP. Mecanismos de transmissão. In: Brener Z,Andrade Z (eds). Trypanosoma cruzi e doença de Chagas. Guanabara Koogan, Rio de Janeiro, p.152-174, 1979.

5. Guartero CM, Ponce EC, Recio R. Cinco nuevos casos de enfermedad de Chagas en Zacatecas y Jalisco de la República Mexicana. Revista de Investigación y Salúd Pública 27:29-36, 1967.

6. Hernández-Gutiérrez RJ, F. Lozano-Kasten, F. Trujillo-Contreras, S. Ruvalcaba. Estudio epidemiológico de la enfermedad de Chagas en el Estado de Jalisco, México. 1987. (Informe preliminar). Nueva Epoca. Revista de Asociación Médica de Jalisco 3:28-33, 1988.

7. Hoare CA. Does Chagas' disease exist in Asia?The Journal of Tropical Medicine and Hygiene 66:297299, 1963.

8. Lozano-Kasten F, Cruz GS, Bartell MG, Prata A, Lopes ER. Doença de Chagas' aguda em mulher de 80 anos no México. Relato anatomopatológico. Revista da Sociedade Brasileira de Medicina Tropical 26:231-235, 1993.

9. Lent $H$. and Wigodzinsky P. Review of the triatominae (hemiptera, reduviidae), and their significance as vectors of Chagas' disease. Bulletin of the American Museum of Natural History 163:3, 1979.

10. Magdaleno PN, Magallón GE, Katthain DG. Prevalencia de Trypanosoma cruzi en triatomas de 50 municipios del Estado de Jalisco, México. In: Memorias de la II Reunión Nacional sobre Enfermedad de Chagas, p.20, 1990.

11. Martins AV. Epidemiologia da Doença de Chagas. In: Cançado JR. Doença de Chagas. Imprensa Oficial do Estado de Minas Gerais, Belo Horizonte, p.225-237, 1968.

12. Michalani J. Técnica histológica em anatomia patológica. Editora Pedagógica e Universitária Ltda. São Paulo, p.40-45, 1980.

13. Sturm NR, Degrave W, Marel C, Simpson L. Sensitive detection of schizodeme classification on Trypanosoma cruzi cells by amplification of kinetoplast minicircle DNA sequences: use in diagnosis of Chagas' disease. Molecular Biochemical Parasitology, 33;205-214, 1989. 